BNWL-SA-5128

Conf $-741070--1$

\title{
HIGH-LEVEL RADIOACTIVE WASTE MANAGEMENT
}

\author{
K.J. Schneider and R. C. Liikala \\ Battelle, Pacific Northwest Laboratory \\ Richland, Washington
}

For presentation at the

1974 Frontiers of Power Technology Conference

at Oklahoma State University

October 9-10, 1974

The research which this paper briefly

summarizes was sponsored by the

United States Atomic Energy Commission,

Division of Waste Management and Transportation, under Contract AT(45-1):1830 


\section{DISCLAIMER}

This report was prepared as an account of work sponsored by an agency of the United States Government. Neither the United States Government nor any agency Thereof, nor any of their employees, makes any warranty, express or implied, or assumes any legal liability or responsibility for the accuracy, completeness, or usefulness of any information, apparatus, product, or process disclosed, or represents that its use would not infringe privately owned rights. Reference herein to any specific commercial product, process, or service by trade name, trademark, manufacturer, or otherwise does not necessarily constitute or imply its endorsement, recommendation, or favoring by the United States Government or any agency thereof. The views and opinions of authors expressed herein do not necessarily state or reflect those of the United States Government or any agency thereof. 


\section{DISCLAIMER}

Portions of this document may be illegible in electronic image products. Images are produced from the best available original document. 


\section{NOTICE}

The report was prepared as an account of work sponsored by the United States Government. Neither the United States nor the United States Atomic Energy Commission, nor any of their employees, nor any of their contractors, subcontractors, or their employees, makes any warranty, express or implied, or assumes any legal liability or responsibility for the accuracy, completeness or usefulness of any information. apparatus, product or process disclosed, or represents that its use would not infringe privately owned rights.

PACIFIC NORTHWEST LABORATORY

operated by

BATTELLE

for the

U.S. ATOMIC ENERGY COMMISSION

Under Contract AT(45-1)-1830 


\title{
HIGH-LEVEL RADIOACTIVE WASTE MANAGEMENT
}

\author{
K. J. Schneider and R. C. Liikala \\ Battelle, Pacific Northwest Laboratories \\ Richland, Washington
}

\section{INTRODUCTION}

Nuclear electrical power capacity is projected to increase rapidly in the United States, from about 15,000 megawatts in 1973 to about 960,0001 (a) megawatts by the year 2000. The power reactors expected to be used include Light Water Reactors (LWRs), High-Temperature Gas Cooled Reactors (HTGRs).. and Fast Breeder Reactors (FBRs), principally the liquid metal cooled type. The nuclear projection by reactor type is shown in Figure I. As shown, the LWRs are the major reactor type expected to be producing power. The activities in the generation of nuclear power are within the nuclear. fuel cycle:

The components of the nuclear fuel cycle are shown in Figure II, which basically represents the cycle for Light Water Power Reactors (LWRS). The logistics of fuel in this cycle starts with the mining of uranium, then goes on to the three processing steps to upgrade the quality of the fuel (milling, conversion, and enrichment), through the fabrication of fuel elements and use of these to produce electrical energy, to the reprocessing of the spent fuel and the disposal of reprocessing residues. In the process of producing fuel either from mining and refining uranium or in recycle of fissionable materials recovered in reprocessing, radioactive wastes are generated. 2 These wastes consist of such things as rags, sweepings, boxes, piping, filters, spent resins, etc., contaminated with small amounts of uranium, plutonium and fission products. However, the average concentration of radioactive materials in these wastes will be low. Similar waste streams are also generated at the reactor plants and the reprocessing facility. The volume of this type of non-high-level waste generated in the various steps of the fuel cycle is several hundred times larger than

a. This is a recent downward revision in AEC report WASH-1139 (74).

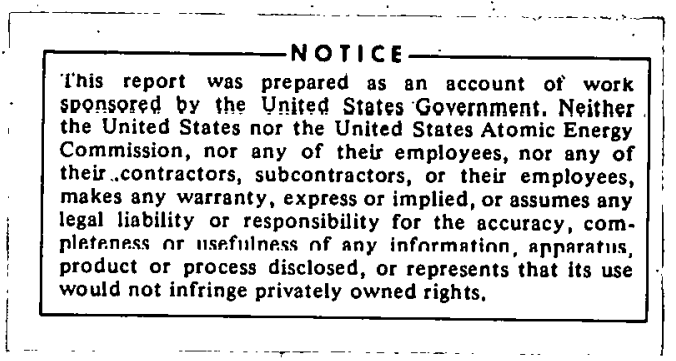


the volume of high-level waste. Other radioactive waste streams associated with the nuclear fuel cycle include cladding hulls, used equipment and the high-level waste that results from reprocessing. The management of this latter waste stream is the subject of this report.

\section{HIGH-LEVEL WASTE PROJECTIONS}

The irradiated or "spent" fuel discharged from nuclear reactors will be chemically processed at fuel reprocessing plants to recover the significant amount of valuable "unspent" fissile and fertile materials for recycle. As an example, irradiated enriched uranium Light Water Reactor (LWR) fuels typically contain about 30 percent of the original fissile uranium and the fissile plutonium that is produced by reactor irradiation. Typical consti. tuents of high-level liquid wastes from the reprocessing of irradiated fuels from LWR, LMFBR, and HTGR plants are shown in Table I. This table was developed for aqueous acidic wastes from first-cycle solvent extraction where the addition of chemicals that could be troublesome in subsequent solidification processes is minimized. Troublesome chemicals include the' water soluble, volatile, or corrosive species or those that result in segregation or phase separation during solidification.

Under present regulations, 3 . this high-level waste must be solidified prior to shipment to a Federal repository. By the year 2000 , about 480,000 cubic feet of solidified high-level waste will be accumulated. This amount of material will generate approximately 600 megawatts of decay heat from some 140,000 megacuries of radioactive residue. The heat will decay to essentially insignificant levels within the first 1000 years; however, the presence of long-lived isotopes (primarily actinides) extends the period of waste management into a much longer time span--perhaps as much as a million years.

\section{WASTE MANAGEMENT PLANS}

Present AEC plans call for the AEC to receive and manage these wastes in retrievable and monitorable storage facilities until one or more methods for ultimate disposal have been selected and developed. 4 Permanent management methods will be developed from various concepts now under study. The feasibility, technical status, safety analysis, development requirements, schedules and costs are being projected to properly assess each concept and provide data for selection of the most promising concepts.

Partitioning prior to disposal is a key element in certain of the conceptual waste management systems. Dividing the high-level waste into two fractions, one in which the major content of radioactively toxic materials will diminish to very low levels in about a thousand years and the other, much smaller in quantity and heat generation rate, but containing long-lived 
TABLE I

TYPICAL MATERIALS IN HIGH-LEVEL LIQUID WASTE

\begin{tabular}{|c|c|c|c|c|}
\hline & & Grams/N & from Rea & or Tyne ${ }^{(a}$ \\
\hline & Material $(r)$ & LWR $(c)$ & $\mathrm{HTGR}^{(\mathrm{d})}$ & $\angle M F B R(e)$ \\
\hline $\begin{array}{c}\text { Reprocessing } \\
\text { Chemicals }\end{array}$ & & & & \\
\hline & Hydrogen & 400 & 3,800 & $\begin{array}{l}1,300 \\
26,300\end{array}$ \\
\hline & Nickel & 100 & 400 & 3,300 \\
\hline & Chromium & 200 & 300 & 6,900 \\
\hline$\cdot \cdot$ & Silicon & -- & 200 & -- \\
\hline & Lithium & -- & 200 & -- \\
\hline$\ldots$ & Boron & -- & 1,000 & -- \\
\hline & Molybdenum & -- & 40 & -- \\
\hline & Aluminum & -- & 6,400 & -- \\
\hline & Copper & -- & 40 & -- \\
\hline & Borate & -- & -- & 98,000 \\
\hline & Nitrate & 65,800 & 435,000 & 244,000 \\
\hline & Phosphate & 900 & -- & -- \\
\hline & Sulfate & -- & 1,100 & -- \\
\hline & Fluoride & & 1,900 & -- \\
\hline & Sub-total & 63,500 & 452,000 & 380,000 \\
\hline Fuel Product & & & & \\
\hline Losses $(f, g)$ & Uranium & 4,800 & 250 & 4,300 \\
\hline & Plutoni um & 40 & $\begin{array}{l}4,600 \\
1,000\end{array}$ & 500 \\
\hline & Sub-total & $\overline{4,840}$ & 5,450 & 4,800 \\
\hline Transuranic & & & & \\
\hline Elements $(\mathrm{g})$ & Neptunium & 480 & 1,400 & \\
\hline & $\begin{array}{l}\text { Americium } \\
\text { Curium }\end{array}$ & $\begin{array}{r}140 \\
40\end{array}$ & $\begin{array}{l}30 \\
10\end{array}$ & $\begin{array}{r}1,250 \\
50\end{array}$ \\
\hline & Sub-total & 660 & 1,440 & 1,560 \\
\hline Other Actinid & $s(g)$. & $<0.001$ & 20 & $<0.001$ \\
\hline Total Fission & Products (h) & 28,800 & 79,400 & 33,000 \\
\hline & TOTAL & 103,000 & 538,000 & 419,000 \\
\hline
\end{tabular}

a. Water content is not shown; all quantities are rounded.

b. Most constituents are present in soluble, ionic form.

c. U-235 enriched PWR, using 378 liters of aqueous waste per metric ton, 33000 MWd/MT exposure. (Integrated reactor power is expressed in megawatt-days [Mwd] per unit of fuel in metric tons [MT].)

d. Combined waste from separate reprocessing of "fresh" fuel and fertile particles, using 3,785 liters of aqueous waste per metric ton, 94,200 MWd/MT exposure.

e. Mixed core and blanket, with boron as soluble poison, $10 \%$ of cladding dissolved, i,24.9 liters per metric ton, 37,100 Mldd/MT average exposure.

f. $0.5 \%$ product loss to waste.

g. At time of reprocessing.

h. Volatile fission produr.t.s (tritium, nohle nases, indine and bromine) excluded. 
materials, substantially increases the waste management options. The shortlived fractions would then decay to become radioactively nontoxic in relatively short times--times short enough to perhaps consider long-term storage such as in manmade structures. The long-lived fraction could be considered for treatment by other management systems. To produce a shortlived waste fraction which would decay to negligible radioactive toxicity in about 1,000 years would require removal of the actinide elements, samarium, technetium, tin, iodine, and nickel (radioactive nickel present due to dissolution of some noncore components).

\section{Solidification of High-Level Waste}

Present Federal regulations require that the liquid high-level waste from fuel reprocessing be converted to a solid material and be encapsulated prior to shipping to a Federal repository for long-term management by the AEC. For conceptual design studies, the solidified high-level waste is assumed to be encased in steel canisters typically 12 inches in diameter and 10 feet long, each container holding 6.3 cubic feet of solid waste. The projected and annual accumulation rates of volumes of solidified waste contained in canisters of this size are shown in Figure III. 5 By the year 2000, the volume of solid high-level waste in terms of the number of canisters will number about 75,000 .

Four solidification processes have been developed in the United States to the point of radioactive demonstration on an engineering scale: 6

- Spray Solidification

- Fluidized Bed Calcination

- Pot Calcination

- Phosphate lilass Solidification

In all four processes, heat is applied to drive off volatile constituents, primarily water and nitrates, resulting in either a calcined solid or a melt that will cool to a monolithic solid.

The Waste Fixation Program (WFP), 7 an AEC Program in progress at the Pacific Northwest Laboratory to develop and demonstrate solidification of high-level waste, has as its chief goal to provide technology for reprocessors by developing and evaluating final waste forms and developing appropriate waste solidification technology. Developed systems will be taken all the way through a radioactive demonstration phase. Solid waste forms from these demonstrations will be studied to determine the effects of time and environment.

The current emphasis of the WFP is to provide early solidification technology by working with silicate glass or ceramic systems. As these solids have had the greatest development effort on a worldwide basis, development of acceptable systems to produce the solids should be nearterm. The silicate solids should offer a vast improvement in waste management safety over liquids or calcined solids. 
In an effort parallel to the silicate solid, development studies are aimed at determining and developing a waste form with even better confinement properties. An example of this would be a multiple-barrier material. This could involve covering small pieces of solid waste with a protective coating. The coated solids could then be dispersed in a protective matrix. Further protection could be provided by outer wrappers.

\section{Retrievable Surface Storage Facility (RSSF)}

For retrievable and monitorable storage of solidified high-level waste in a surface facility, several al ternative RSSF concepts based on the enclosed basin or vault type of storage with air or water cooling of the waste are being developed by the Atlantic Richfield. Hanford Company for the AEC. 8,9 Selection of a final concept and site is anticipated later this year.

The Retrievable Surface Storage Facility (RSSF) will comprise facilities for receiving and inspecting packaged wastes from fuel processors and facilities for safely storing these wastes. The facility will be designed to hold safely, for at least 100 years, if necessary, all of the commercial high-level waste produced in the United States at least through the year 2000 .

Basically three RSSF concepts are under consideration by the AEC, the Water Basin Concept, the Air-Cooled Vault Concept, and the Sealed Cask Concept.

In the Water Basin Concept, the canisters are stored in water-filled stainless-steel-lined concrete basins. The concept consists of three major elements: the waste receiving and handling facility; the storage facility, a series of water-filled concrete basins in which the wastes would be placed for cooling and long-term surveillance; and the heat rejection facilities (forced-draft cooling towers).

In the Air-cooled Vault Concept, the waste canisters would be sealed by welding them inside another carbon steel container. This assembly is then placed inside concrete vaults to be cooled by natural draft convection. The three major elements of the concept are the waste receiving and handling facility, the welding and testing facilities, and the canister storage cells.

In the Sealed Storage Cask Concept, the canisters would be sealed in steel casks which would be stored outdoors on concrete pad's and inside concrete neutron shields as shown in Figure IV. Heat would be dissipated from the casks by natural convection airflow through the annulus between the cask and the neutron shield. The three major elements of the concept are the waste receiving and handling facility, the storage cask welding and testing facility, and the outdoor waste cask storage areas. 


\section{Potential Future Alternatives}

Availability of a safe storage mode for storage of wastes for periods on the order of 100 years will provide adequate time for development of an ultimate disposal concept.

For this reason, an extensive program is under way to identify, evaluate and possibly demonstrate feasible alternative disposal techniques for later use. Studies of disposal in bedded and domed salt formations as well as disposal in other geologic media have been and are being conducted by Oak Ridge National Laboratory for the AEC.10,11 Studies of other alternatives for managing high-level waste are being conducted by Battelle; Pacific Northwest Laboratories (Battelle-Northwest) for the AEC.12 There are large deposits of rock salt in various locations in the U.S. The salt mine concept is based upon the principle of isolating the high-level wastes in a stable underground salt formation. Studies are under way to evaluate and demonstrate safe and competent, receiving, handling, emplacement, and retrieval operations as well as providing means to demonstrate the adequacy of analytical techniques used to predict the long-term stability of salt and other geologic formations when they contain heat-producing waste.

\section{ADVANCED WASTE STUDIES CONDUCTED BY BATTELLE-NORTHWEST}

The AEC has commissioned Battelle-Northwest to make a comprehensive evaluation of all potentially attractive disposal concepts. The purpose of this evaluation is to identify feasible and potentially feasible longterm waste management systems and their components, evaluate the safety of these systems, identify the research and development necessary for their establishment, and estimate the schedule and costs associated with selected systems. This work has been published in summary form 13 and in detai1.14

Three basic types of waste management concepts are under study: (7) disposal on earth, (2) disposal in space, and (3) conversion by nuclear processes called transmutation. The earth disposal concepts involve use of geologic formations, ice sheets and the seabed. The space disposal concept involves transporting waste to various orbits or trajectories in space. Transmutation involves elimination of some of the more offensive waste nuclides by nuclear transition. Alternatives within these categories are listed in Table II.

Study Methodology

The overali method of analys is by which each disposal concept and its waste management system elements were studied is presented briefly in this section. 14 The relationships among the major study elements are shown in Figure $V$. 
CONCEPTS UNDER STUDY FOR HIGH-LEVEL

RADIOACTIVE WASTE MANAGEMENT

\title{
A. PROCESSING
}

Partitioning $^{(a)}$

B. DISPOSAL ON THE EARTH
Geologic
Mined Cavity
Nuclear Cavity
Deep Hole
Drilled Hole Matrix
Manmade Structures in
Geologic Formations
Hydraulic Fracturing

Seabed

Ice Sheet

Stable Deep Sea Floor

Ice Burial - Free Flow

Subduction Zones and Deep Trenches

Ice Burial - Anchored

Rapid Sedimentation

Ice Surface Facility

C. DISPOSAL OFF THE EARTH

Extraterrestrial

Solar Impact

Earth and Solar Orbit

Solar Escape to Deep Space

\section{ELIMINATION}

\section{Transmutation}

\author{
Accelerator \\ Fission Reactor \\ Nuclear Explosive \\ Controlled Thcrmonuclear Reactor \\ (Fusion Reactor)
}

a. Partitioning is a chemical separation of waste constituents into two fractions: one which contains the long-lived actinide elements and one which contains the fission products. Variations from this basic definition are also included in the study. 
The waste management concepts were first developed to the detail needed to describe them for overall investigations and in general were studied on a systematic, generic basis. Concepts were generally developed on the reference basis of having the capability to handle the waste from a plant which reprocesses 5 metric tons/day ( $1825 \mathrm{MT} / \mathrm{yr}$ ) of spent nuclear fuel.(a) This reference capacity was then scaled up as a function of time to accommodate the total need for the U.S. nuclear economy through the year 2000.

After the various disposal concepts were defined, the technical feasibility of each potential concept was determined in this study by answering the questions:

1) Can the disposal concept be implemented using today's technology?

2) Or can the disposal concept be implemented with future technology based upon current theory?

3) Can the disposal concept provide the potential for confining or eliminating the waste over the required time period?

4) Does the concept have a favorable energy balance?

Those few concepts that did not pass this technical feasibility test (i.e., some transmutation and space disposal variations) were rejected from further studies. Once the technical feasibility of a concept was established, the other elements were studied in parallel.

The potential for system safety was scanned for each concept. A sample safety analysis was performed for one generic type of geologic disposal concept to develop and test the safety analysis methodology.

Safety is a major consideration in decisions on the use of any potential disposal scheme. An acceptable option must provide adequate protection during operational phases and provide the necessary isolation during the disposal phase. For this study "safety" is equated directly to the potential risk to man that could result if the disposal option were implemented.

As shown in Figure VI, the overall matrix, starts with defining the general characteristics of the disposal concept. The next step is evaluation of the most likely sequences of failure events leading to release of radioactive materials to man's environment and determination of the probability of these sequences taking place. The next step follows the most likely sequences through the physical and chemical processes required to release the waste constituents into man's immediate environment. The characteristics of the waste must be dealt with parametrically at the time the critical

a. High-level waste produced is about 19001 iters/day as aqueous waste. This quantity amounts to 45,625 metric tons of fuel reprocessed during the assumed 25-year life of the plant. Total accumulated solid waste is in 14,700 "typical" canisters 12 inches in diameter and 10 feet long. 
event takes place. The generic site defines the media (granite, salt, shale, soil, air, water, etc.) through which radionuclides must move. Finaliy, based on the population as indicated for the generic site and the calculated release rate, the dose to the surrounding population can be estimated.

The probabilistic risk to man can be determined by multiplying the probability of the event taking place times the radiological dose if the event happened. By comparing each of these doses with appropriate criteria, it can be determined whether or not the risk to man exceeds acceptable criteria. If the risk. level is unacceptably high, changes could be made in the concept to improve the level of risk. If the risk for a concept meets all criteria, the concept will be considered to have met the safety requirements.

Environmental considerations, aside from the potential release of radioactive materials, were reviewed such as overall effects on land, air, sea or water use.

The technology needs were assessed, and research and development needs (scope, time, and dollars) were estimated. From the research and development time needs, the total time for implementation of each concept was estimated.

Capital and operating costs were estimated, using the basic assumption that the necessary research and development had been successfully completed. Costs were estimated and summed for total waste management system activities such as partitioning, interim liquid and solid storage, shipping and disposal.

Major policy conflicts that a concept would have with international and national policies were reviewed such as agreements that prohibit the use of the oceans or the Antarctic continent for waste disposal. The problems involved with changes can then be weighed against the safety and economic potentials of a particular waste management concept.

The potential public response to a chosen waste management scheme was examined in a preliminary pilot test. Obviously this is a complex subject and very difficult to evaluate. An initial study of methodology was designed to identify those aspects of the waste management systems that might be deemed most important by the general public. With future analysis in depth, information on public attitudes could be factored into concept design. The public's acceptance of a technically sound waste management system is a most important goal.

The final product of the study is a compilation of information regarding the evaluation factors for the various disposal concepts. The outcome of each of these elements is described in different units. Therefore, the concepts cannot be evaluated by simply adding up the performance level by elements. Instead, techniques are being developed for future studies to determine if a disposal concept passes a performance test for each evaluation factor listed. 


\section{Geologic Disposal Concepts}

Geologic environments exist which have been physically and chemically stable for millions of years, are isolated from man's environment, and can potentially provide effective barriers between waste and man's environment for the time periods required. The basic requirement for any geologic environment to be suitable for disposal of radioactive waste is the capability to safely contain the emplaced radioactive material until decay has reduced the radioactivity to nonhazardous levels. The geologic environment should (a) be adequately far removed from man's environment, (b) not permit waste transport readily, (c) remain relatively stable over geologic time periods, and (d) adequately contain a highly immoblle waste form.

The geologic disposal studies involved evaluation of concepts with variations in emplacement systems and in geologic environments. The methods under consideration for disposal of radioactive waste in a given geologic formation include:

1) Placing solidified waste directly into a geologic formation.

2) Placing solidified waste in manmade containment barriers within a geologic formation.

3) Placing solidified waste in a geologic formation in a configuration to allow the waste to melt and form a rock-waste matrix.

Each of these basic concepts has a number of variations, as listed in Table III. Two primary disposal geometries, i.e., cavities and a drilled hole, several means for forming cavities, and several operational modes were examined.

In all concepts the final waste form is a solid. In some concepts, waste is emplaced in the geologic formation as a liquid and converted inplace to a solid form for long-term disposal. For concepts 5, 6, and 9, the self-generated heat within the liquid waste is used to dry and melt the waste and some of the surrounding rock which, when cooled, forms a solid waste-rock matrix. In concept 10, the liquid waste is incorporated within a self-curing cement.

Because of the potential hazards of shipping aqueous high-level waste, the liquid emplacement concepts require locating the fuel reprocessing plant at the disposal site. The solid emplacement concepts involve transportation of the waste, already converted to a solid at the fuel reprocessing plant, cross-country to a central Federal disposal site, assumed to be separate from the reprocessing plant.

Disposal of previously solidified waste in a conventionally mined cavity, shown in Figure VII, is one of the more basic concepts under study and 
CHARACTERISTICS OF GEOLOGIC DISPOSAL CONCEPTS

\begin{tabular}{|c|c|c|c|c|c|}
\hline & $\therefore$ Concept & Type of Cavity & $\begin{array}{l}\text { Waste Form } \\
\text { at Time of } \\
\text { Emplacement }\end{array}$ & $\begin{array}{c}\text { Fluid } \\
\text { Cooling } \\
\end{array}$ & $\begin{array}{r}\text { Waste-Rock } \\
\text { Reactions }\end{array}$ \\
\hline & $:$ & Mined & Solid & No & No \\
\hline & $\because:$ & Mined & Sol id & Water & Melt \\
\hline & 3 & Mined (a) & Solid & $\operatorname{Air}(c)$ & No. \\
\hline & 4 & $\operatorname{Mined}^{(a)}$ & Solid & Water $(c)$ & No \\
\hline & 5 & Mined & Liquid (b) & No & Melt \\
\hline . & 6 & Exploded & Liquid (b) & No & Melt \\
\hline$\therefore \because \because$ & : $\cdot$ & $\begin{array}{l}\text { Matrix of } \\
\text { Drilled Holes }\end{array}$ & Solid & No & No \\
\hline & 8 & Deep Hole & Solid & No & No/Melt ${ }^{(d)}$ \\
\hline$\because$ & $\therefore \quad 9$ & Deep Hole & Liquid (b) & No & Melt \\
\hline & $\therefore \quad 10$ & Hydrofracture & Liquid (b) & No & No \\
\hline
\end{tabular}

a. Includes underground manmade structures.

b. All liquid emplacement concepts involve in-place conversion to a solid form.

c. Cooling is provided for an interim period of tens of years until the heat generation rate has decreased to a point that melting will not occur.

d. This deep hole concept is studied for both melting and nonmelting cases. 
is used here to illustrate a geologic disposal alternative. It would use a building above ground to receive the waste canisters and transfer them to the underground area. The waste canisters are placed in storage pods located in lined tunnels. The storage pods are air-cooled, though other means of cooling appear feasible. After an appropriate time period (generally tens of years), the cooling system can be shut down and the repository permanently sealed.

All geologic concepts appear to be technically feasible. Cavities and holes could be made today with the possible exception of the very deep hole. A deep hole could probably be drilled today in areas with very low geothermal gradients, but new technology is required for the moderately large holes needed at the great depth (10 miles) and for the high down-hole temperatures encountered at great depth.

Nuclear explosive technology is available, but evaluation of the significance of fractures that will be produced by the detonation would be most difficult. It is not certain whether sufficient technology exists today for implementing the waste-rock melting concepts. Melting can certainily be accomplished, but the conduct of the molten mass and its effect on the surrounding media are not yet certain.

Final sealing of the access holes is required for geologic concepts for the long time period of concern. Such high-integrity sealing, necessary to maintain long-term isolation of the waste from man's environment, has not been considered heretofore by industry. Existing sealing techniques mus.t be tested (and improved if necessary). for radioactive waste disposal.

Key factors to avoid in siting ${ }^{15}$ are areas with: 1) potential for hydrologic transport; 2) usable groundwater; 3) seismic potential, including fault densities; 4) resource potential; and 5) significant population density.

of the various geohydrologic factors considered in evaluating potential sites for disposal the most important is hydrologic isolation; this is to assure that the waste will be effectively contained within an acceptable radius of the emplacement zone. To achieve this degree of hydrologic isolation, the host rock for the waste should exhibit a very low permeability and the site should be virtually free of geologic faults.

The most suitable rock media for the various concepts considered appear to be (a) 1) intrusive igneous rocks(b) (e.g., granite) or crystalline metamorphic rocks $(c)$ (e.g., quartzite) because of their low permeabilities and

a. No order of preference was established in this study nor is it implied here. Much more information is available regarding disposal in salt than in these other rock media.

b. Intrusive igneous rocks are those formed by cooling and solidification of a molten rock mass that invaded the earth's crust but did not reach the surface.

c. Crystalline metamorphic is a general term used here for the more granular, coarse-grained rocks that have been changed in texture or composition by heat, pressure, or chemically active fluids after their formation. 
high mechanical strengths, 2) salt, either in stable domes or thick beds because of its low permeability and self-sealing property, and 3) tuff (welded volcanic ash) and shale because of their very low permeabilities and high ion-exchange capacities. Sedimentary rocks other than shale and salt, and volcanic rocks, exclusive of tuff, are considered generally unsuitable for waste emplacement because of their potential for high permeabilities. 15

Areas appearing potentially suitable as waste repositories based on this study have not been defined. The numerous other geologic factors important for waste disposal cannot be covered within the scope of this paper.

Overall, disposal of radioactive waste in geologic formations has the potential of isolating the waste from man's environment for extended time periods (millions of years). Certain geologic formations can serve as effective barriers because of their known long-term physical and chemical stability and their isolation from man's immediate environs.

\section{Seabed Disposal Concepts}

Disposal. of high-level waste within the floors of the world's oceans offers another possibility for permanent isolation of the waste from man's environment. The depth to the floor or seabed would provide isolation and safety from natural disasters such as storms, as wel't as ifrom planned or unplanned disturbance by man. The large volume of seawater could help cool the waste. The known high ion-exchange capacity of the seabed sediments would aid in immobilizing waste material if any waste escape should occur.

A number of seabed disposal concepts are being evaluated, but all are basically the same except for the site. The following geologically distinct types of sites on the seabed are being considered:

1. Stable Deep Sea Floor--areas such as deep ocean basins and abyssal plains, which are considered geologically stable. The waste would be placed in the bedrock below the unconsolidated sedimentary cover.

2.. Subduction Zones/Deep Sea Trenches--areas where, according to crustal plate tectonics theory, one edge of certain crustal plates is moving under the other crustal plates and down into the earth's mantle. The waste would be placed in these trench areas to be carried down, or subducted, into the earth's mantle with the crustal plate.

3. High Sedimentation Rate Areas--areas where major rivers are building deltas into the ocean. The waste would be placed in the bedrock below the accumulating deitaic sediments. 
The radioactive waste would be in a solid form and enclosed in a durable sealed canister. To further isolate wastes, the canisters would be placed in prepared holes in the basement rock under the sea, after which the holes would be sealed. The depth of the prepared holes would depend on the nature of the seabed at the disposal site.

A schematic description of the seabed concept is shown in Figure VIII. The previously solidified and canned bulk waste from the reprocessing plant would be transported in protective casks to special ports of embarkation for inspection and possible short-term storage. The waste would then be transported in protective casks by ships to the disposal site where a number of waste canisters would be placed in each predrilled hole in the basement rock from a special drilling platform and the upper section of each hole would be filled with a sealant.

Implementation of the seabed disposal concepts in the stable deep sea areas and in the areas of rapid sedimentation could be attained with today's technology, but a number of years would be required for development to prove the safety of the concept. Significant development of drilling and emplacement technology would be required to implement disposal in the very deep sea areas of the trenches and the subduction zones. Final sealing of the disposal holes to maintain isolation for the long time periods of concern would need to be tested (and improved if necessary) for radioactive waste disposal.

Because of their relative geologic stability, the stable deep areas are considered the preferred areas for seabed disposal, based upon present knowledge. Proper selection of sites in these areas could provide potential isolation of radioactive waste for very long time periods. These stable seabed areas are considered to be among the most stable geophysical features in the earth.

Overall, disposal of radioactive waste in the seabed has the potential for isolating waste from man's environment for periods in the order of millions of years, depending upon confirmation of inferred information by future seabed exploration.

\section{Ice Sheet Disposal Concepts}

Concepts for radioactive waste disposal in the major ice sheets of the world (Greenland and Antarctica) are being evaluated. Potential advantages are great thicknesses of ice, remoteness from man's activities, and low likelihood for future development. The ice could provide effective direct cooling for the waste and, at the same time, maintain isolation from man's. environment.

Three potential disposal concepts are being evaluated for the ice sheet areas such as Antarctica or Greenland.

1. Meltdown or Free Flow--the waste canister would be placed in an individual shallow drilled hole in the ice and allowed to melt down through the ice sheet to bedrock. 16 
2. Anchored Emplacement--the waste canister would be placed in an individual shallow drilled hole in the ice but connected to surface anchors by cables or chains, which stop its descent and maintain its position (500 to 1500 "feet below the ice surface) for up to about 100 years.

3. Surface Storage/Disposal--the waste canister would be placed in a temporary hot cell type of storage facility with jack-up piers on the ice sheet surface. After about 50 years, the facility would be allowed to become covered by, accumulating snow and would be eventually buried in the ice sheet for final disposal.

A schematic description of the ice sheet concept is shown in Figure IX. It consists of transporting previously solidified and canned bul.k waste in protective casks from the reprocessing plant to special embarkation ports. The waste would then be transported in protective casks by ships to the edge of the ice sheet when the waste canisters and casks would be off-loaded to a debarkation facility near the edge of the continent. Surface vehicles would provide over-ice transport to the disposal site.

All ice sheet disposal concepts could be implemented with today's technology, but a number of years would be required for development to prove the safety of any concept. Containerization, transportation, and emplacement could all be accomplished by modification of technology. In all concepts final sealing of the waste would be performed by natural refreezing of the water around the waste.

Overall, disposal of radioactive waste in ice sheets is considered to have an uncertain potential for isolating waste from man's environment, depending largely on ice flow rates and lack of certainty that the ice sheet will remain in existence for 1000 to $1,000,000$ years. Assuming the key questions can be answered favorably, disposal of radioactive waste in ice sheets could have the potential for isolating waste from man's environment for long time periods.

\section{Extraterrestrial Disposal}

Disposal of radioactive waste by removing it from the earth with rockets is another potential disposal concept. If a stable non-earth intercept trajeclury ur orbit can be assured, extraterrestrial disposal offers a method for the complete removal of long-lived nuclear waste constituents from the earth. The primary unfavorable features are that the concept deals with only part of the waste, there are possible launch safety problems, retrievability and monitoring are difficult, and there is possibility for International disagreement.

Extraterrestrial disposal of the total waste constituents and of only the actinides are both considered. However, primarily because of the high transpurt cust per unft of weight, space disposal of just the actinides is believed the most practical scheme. The remaining waste would have to be disposed of by some other means. 
The launch deployment sequence using a shuttle and a tug is shown in Figure $X$. Typically, the shuttle would be launched into a low circular earth orbit. From this orbit, the tugs or upper stage(s) would be launched to carry the waste package to its final destination. 17

The implementation of space disposal of actinide waste could be achieved with current technology, but the safety of the concept cannot yet be established. This technology is considered to include the space shuttle (with separately retrievable and reusable lift-off-assist rockets) and the space tug, which are advanced vehicles but which will use existing engineering technology.

The destination considered most likely with current chemical rockets is escape from the solar system. Impact into the sun cannot be done without advanced technology or very complex swing-by's of other planets. Solar or high earth orbits cannot currently be assured for periods greater than about 1000 years. The development of advanced technology vehicles (e.g., ion rockets, solar sails, etc.) could perhaps change the potential destinations in space.

\section{Transmutation Concepts}

Another possible approach to the management of radioactive waste is the use of nuclear processes themselves to change (transmute) the hazardous longlived radioactive waste constituents into short-lived radioactive waste or nonradioactive isotopes. Transmutation is generally defined as any process whereby a nuclide absorbs or emits radiation and is thereby transformed into another nuclide. It is theoretically possible through use of nuclear processes themselves to achieve the transmutation.

The results of the evaluation for the various transmutation alternatives are summarized in Table IV. The accelerator devices failed to meet technical feasibility criteria for transmutation for essentially all categories of radioactive waste. The only possible exception is the use of a spallation neutron source for transmutation of long-lived fission products. Likewise, use of neutrons from a thermonuclear explosion does not appear technically feasible. The use of fission and fusion reactors appears feasible for transmutation of actinides. Fusion reactors also may transmute selected fission products.

Calculations $18,19,20$ indicate that significant reductions are possible in the cumulative toxicity index of actinides by recycle in fission reactors. (Toxicity index is defined as the amount of air or water required to dilute the present amount of a given isotope to levels defined in the Code of Federal Regulations, 10 CFR - Part 20.) The calculations indicate that using existing separations efficiencies with recycling of actinides in Light Water Power Reactors could achieve an order of magnitude decrease in the short-term actinide toxicity indices and about a factor of fifty decrease in the long-term toxicity index. These reduction factors may be significantly improved by achieving higher separations efficiencies, by better optimization of the reactor irradiation, or by recycling in LMFBRs. 
TABLE IV

SUMMARY OF TRANSMUTATION DEVICE FEASIBILITY $\because ; \cdot$

Technically Feasible for Transmutation

Accelerators

- Electron Accelerator

- Proton Accelerator

- Spallation Accelerator

Category $1^{(a)}$ Category $2^{(a)}$ Category $3^{(a)}$ Category 3

Nuciear Explosives

No

No

No

No

Fission Reactors

No

No

- No

No

No

Possibly

No

No

Yes

No

No

Possibly

Yes

Fusion Reactors

Possibly ${ }^{(b)}$ Possibly (b)

Possibly

Yes

Fusion Reactors

$$
\text { . }
$$

Yes

Yes

a. Category 1: Storage required for 100 years Category 2: Storage required for 100-1000 years Category: 3: Storage required for 1000 years

b. Separated isotopes 
Calculations also show that neutron-induced transmutation of actinides and fission products in the blankets of hypothetical Controlled Thermonuclear Fusion Reactors (CTRs)21 could reduce the cumulative toxicity index of actinides by a factor of 10 or more below that achievable in fission reactors. These studies have also shown that large reductions in the respective toxicity indices are possible for some fission product elements. For others; notably strontium and cesium, the degree of toxicity reduction is minimal. A 11 considerations of radionuclide transmutation in CTRS, of course, presuppose the successful accomplishment of controlled thermonuclear fusion.

Since it is technically feasible to transmute actinides by recycle in fission reactors and CTRs and certain fission products in CTRs, these two reactor technologies combine to form a potentially viable long-term (year 2000 or 2010), the actinides separated from the rest of the waste would continue to be recycled in fission reactors with the fission products stored in a retrievable facility. In the long-term, with the advent of CTRs, the fission products could be retrieved trom storage and recycled along. with the actinides in the CTR. In either strategy, some of the fission products and whatever "heel" of untransmuted waste at the end of this era must be disposed of by other means.

\section{Waste Partitioning}

The extraterrestrial and transmutation schemes require partitioning (separation) of actinides from the remaining waste constituents.

For removal of actinides from the fission products, the separation requirements are not clear because the ultimate answer to the question of "at what radioactivity level can a material be considered as not radioactive" depends highly on the specific disposal technique and site. It is also complicated by the need for higher decontamination (separation) factors for some actinides than for others. The required separation factors can range from as $10 \mathrm{w}$ as 10 to as much as $10^{6}$ to $10^{8}$, depending upon assumptions and specific case conditions. The more likely case is somewhere in the middle of the range and is believed to be between 100 and 10,000 .

An overview study was made of all chemical separations processes which might be applicable to partitioning of actinides from bulk liquid waste. The conclusions indicate that solvent extraction partitioning of the waste is feasible for low to moderate separation factors and is uncertain for high separation factors.

\section{Safety}

For this study "safety" was equated directly to the potential risk to man (in terms of radiation dose) that could result if a disposal option were implemented. The key elements in a method of assessing potential risk were illustrated earlier in Figure VI.

Evaluation of the safety of any disposal concept requires identification of mechanisms and probabilities of possible releases of radioactive waste constituents to man's environment. The fault tree analysis technique was 
selected as the method to achieve these requirements. The method provides for calculating the risk to man (in terms of radiation exposure in this study) on a probabilistic basis.

A generic fault tree was developed for geologic disposal in a mined cavity. In al1, 77 basic failure events were identified as possible contributors to a waste release from a geologic disposal site. One release sequence, obtained from the geologic fault tree developed in the study was analyzed, based on very limited data.

The example waste release sequence considers the release of waste to man's environment by water. This is considered to be one of the more likely release sequences.

The release sequence starts with the premise of "An Aquifer in the Waste Disposal Region" and requires the following three conditions: "Water Finds. Path into Disposal Site," "Water Is Flowing" and "Water Flow Cannot be Controlled by Man." All three conditions must occur together before a release of waste constituents can take place.

From the analysis. the probability of release of waste from the geologic repository was estimated to be in the range of $10^{-14}$ to $10^{-10}$ during the operational period, $10^{-10}$ to $10^{-6}$ during the next 1000 years, and $10^{-6}$ to $10^{-3}$ during the first $1,000,000$ years.

Next, assuming release of waste from these hypothetical failures, sample transport decontamination factors were calculated for an aquifer 10 miles long flowing at $1 \mathrm{ft} /$ day in typical western soil to estimate the radionuclides which could enter man's environment. This calculation assumed that an aquifer penetrated a failed barrier in a gelogic disposal site. Dose reduction factors were in the range of $10^{5}$ to $10^{6}$; that is, the calculated doses to man.with soil retention were 5 to 6 orders of magnitude lower than those without soil retention. The significance of this calculation is that for properiy sited disposal concepts, the earth itself can provide major safety. factors.

Dose to man from the hypothetical releases was then estimated using a comprehensive dose computational model based on pathways of radionuclides within man's environment. These calculations showed maximum radioactivity dose to individuals to be in the range of $0.4 \mathrm{mrem} /$ year, and to a large population group in the range of $30 \mathrm{man}-\mathrm{rem} /$ year for the operational period. Doses during the longer periods would be significantly less because of decay of radionuclides.

Based on these calculations, the maximum measure of risk to an individual from the given fajlure mechanisms and pathways would then be in the range of $10^{-14}$ to $10^{-10} \mathrm{mrem} /$ year to the whole body during the operational pertod, $10^{-10}$ to $10^{-6} \mathrm{mrem} /$ year at 1,000 years after disposal, and $10^{-6}$ to $10^{-3} \mathrm{mrem} /$ year at $1,000,000$ years after disposal. Similarly, the risk to the affected large population group would be less than $10^{-8}, 10^{-4}$, and $10^{-1}$ man-rem/year for the same respective three time intervals. 
These sample calculations demonstrate the methodology for calculating the probabilistic risk to man from radioactive waste disposal. For actual application of risk calculations, analyses will be required for specific concepts, sites, and operations. In addition, the risks from all major mechanisms and pathways must be summed to obtain the total calculated risk.

Research, Development, and Timing

All of the potential alternative waste concepts require research and development before they can be implemented. The time requirement to complete the research and development in all concepts is the primary controlling factor in the time that the concepts can be implemented. A summary of the estimated research and development needs and the estimated nearearly time for implementation of the disposal concepts on a routine production basis is presented in Table $V$. The research and development studies for all concepts are assumed to terminate upon successful completion of pilot-scale demonstrations.

The waste management research and development costs for ice sheet and seabed concepts are believed to be the highest, based primarily on need for basic geophysical data. Some geologic disposal concepts have estimated research and development costs as low as $\$ 50 \mathrm{million}$, but others are as high as $\$ 180$ million, which almost spans the estimated range for space and transmutation concepts.

Most concepts appear to require an estimated 15 to 35 years of research, development, and pilot testing prior to routine operation.

\section{Waste Management Costs}

A highly preliminary analysis of waste management costs for each disposal concept was developed by taking into consideration all of the necessary components of a complete waste management system. The system cost includes, for example, any added spent fuel transport, interim liquid waste storage, waste solidification, interim solid waste storage, and transport of solid waste canisters to the disposal site or port of embarkation in the case of seabed or ice sheet concepts.

Disposal costs were developed in terms of levelized unit charges--the single charge that could be assessed over the entire life of a project against each unit processed that would recover all operating expenses as well as the initial investment plus a specified rate of return on the investment. A $10 \%$ interest rate was employed.

The resultant preliminary cost estimates for each of the disposal concepts are shown in Table VI. Estimates are shown for both the direct concept costs and for the waste management system costs. The direct concept total capital and operating costs are shown in terms of estimated, levelized unit charges present worthed to the time of reprocessing. The present worthing somewhat obscures the relationship between capital and operating costs and the levelized unit charges because of differences in elapsed time from reprocessing to final disposal for some of the concepts. 
TABLE V

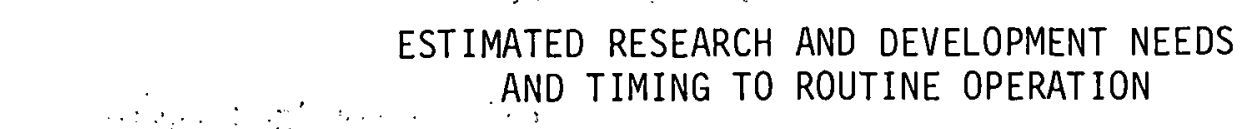

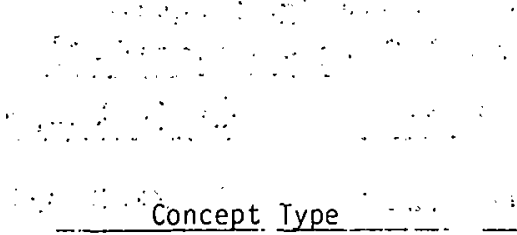

: Geologic Disposal

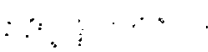

$\therefore \therefore \therefore$.

Seabed Disposal

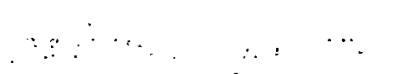

Icè Sheet Disposal.
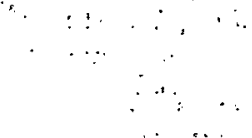

Extraterrestrial Disposal

$$
\therefore \because
$$

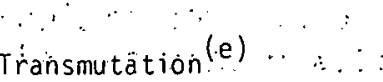

$$
\begin{aligned}
& \text { Partitioning development; neu- } \\
& \text { tronics data analysis and mea- } \\
& \text { surements; fuel development; } \\
& \text { safety evaluation; } \\
& \text { demonstration }
\end{aligned}
$$

\begin{tabular}{|c|c|c|}
\hline $\begin{array}{c}\text { Cost Range, } \\
\text { Millions } \\
\text { of } \$ \\
\end{array}$ & $\begin{array}{l}\text { Time Range, } \\
\text { years }\end{array}$ & $\begin{array}{c}\text { Total Time } \\
\text { for Operation, } \\
\text { years }(a) \\
\end{array}$ \\
\hline $50-180$ & $15-25$ & .. 15-35 \\
\hline$\because$ & $\cdot$. & $\therefore$. \\
\hline & . & $\therefore \quad:$ \\
\hline & & . \\
\hline $400-1000^{(b)}$ & 25 & 30 \\
\hline
\end{tabular}

$$
\begin{array}{cccc}
600-1000^{(b)} & 25 & & 30 \\
& & & \\
200(c) & 20 & \ddots 20
\end{array}
$$

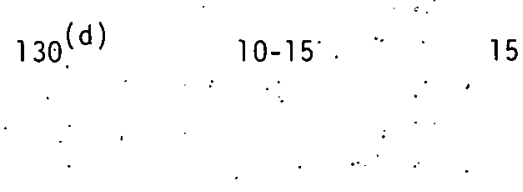

a. Includes research and development time:

b. Ice sheet and seabed costs are very difficult to estimate. The estimated ranges given are highly speculative. About four times the estimated costs shown here will be required for basic geological/geophysical and related earth science studies; the costs estimated in this table would be aimed specifically toward waste disposal.

c. Space research and development costs do not include costs for basic flight vehicle and auxiliaries development; these costs (in many millions of dollars), are assumed to be borne by NASA for other space flight activities. Costs include an estimated $\$ 100 \mathrm{mill}$ ion for space vehicle and trajectory development specific to waste disposal, and disposal of remaining waste fraction by the terrestrial concept. with lowest research and development cost ( $\$ 50$ million). Costs and timing for solàr impact were not estimated.

d. Includes industria? participation estimated at 50 million dollars and disposal of remaining waste fraction by the terrestrial concept with the lowest research and development cost (\$5n million).

e. For transmutation of actinides in fission reactors. Research and development for fusion reactors was not evaluated. Requirements are dictated by advent and engineering of fusion reactors. Rescarch and development for accelerator transmutation was not evaluated. Feasibility of concept is uncertain. 


\begin{tabular}{|c|c|c|c|}
\hline \multirow[b]{2}{*}{ Concept Type } & \multirow{2}{*}{$\begin{array}{l}\text { Direct Levelized } \\
\text { Disposal Costs, } \\
\$ / M T \text { Fuel (a) } \\
\end{array}$} & \multicolumn{2}{|c|}{$\begin{array}{c}\text { Total Levelized Waste } \\
\text { Management System Costs (a,e) }\end{array}$} \\
\hline & & $\$ /$ MT Fuel & mills $/ \mathrm{kW}-\mathrm{hr}$ \\
\hline Geologic Disposal & $700-8,500$ & $6,300-17,000$ & $0.024-0.064$ \\
\hline Seabed Disposal & $5,000-8,000$ & $14,000-17,000$ & $0.052-0.063$ \\
\hline Ice Sheet Disposal & $12,000-15,000$ & $20,000-24,000$ & $0.077-0.090$ \\
\hline $\begin{array}{l}\text { Extraterrestrial } \\
\text { Disposal }(b, c, d)\end{array}$ & $30,000-80,000$ & $40,000-90,000$ & $0.15-0.34$ \\
\hline Transmutation $(h, r)$ & 28,000 & 30,000 & 0.15 \\
\hline
\end{tabular}

a. Cost present worthed to time of reprocessing.

b. In the case of Transmutation and Extraterrestrial disposal concepts, the concept cost given in this table includes the cost of disposing actinides and transuraniums only. Additional costs of disposing of the remaining waste must be added to obtain total waste management costs. A representative cost for terrestrial disposal of the remaining waste fraction of $\$ 10,000 / \mathrm{MT}$ or $0.04 \mathrm{mills} / \mathrm{kW}-\mathrm{hr}$ is added to the transmutation and extraterrestrial costs and listed in the last column to show a total waste management system cost.

c. Costs for Transmutation and Extraterrestrial disposal concepts were obtained somewhat differently than for terrestrial concepts. Transmutation costs assume the use of commercially owned facilities.

d. Range for space disposal is for high earth orhit. (1ower values) and escape from the solar system (higher values).

e. System cost includes extra transport costs, interim liquid storage, partitioning, solidification, etc. 
These estimates conclude that the levelized unit cost for the most expensive concept (extraterrestrial solar escape disposal) is less than five percent of current nuclear electric power costs; most concepts are in the range of 0.4 to 1.0 percent; and two concepts are in the range of 0.2 percent. Consequently, none of the disposal concepts is estimated to increase the cost of nuclear electric power by major amounts.

\section{Nonradiological Environmental Considerations}

Exclusive of the possible dose consequences of radionuclide release. from the waste, in only a few specific cases were any significant environmental effects indicated. Environmental effects are estimated for disposal in the year 2010 for the waste accumulated in the U.S. through the year 2000 .

Geglogic concepts would commit typically about 130 square kilometers of land (a) but have little other impact other than disposal of mining spoils. Some transportation impact would result from an estimated 12,500 shipments to the disposal site by the year 2010 .

Because the ecology of the ice sheet regions is fragile, care would be required to ensure that the transportation and emplacement operations did not seriously disrupt it. Total ice sheet area used would be about 80,000 square kilometers. Up to ten trips per year would be required for overocean ship transport.

Seabed concepts would require the isolation of an area of some 2,000 square kilometers from other seabed activities. Truck or rail shipment would be required to the port of embarkation. An estimated 60 annual round trips "to the drilling platform would be required for movement of personnel, small materials, and supplies. Up to ten trips per year would be required for transporting waste to the platform.

Extraterrestrial launches of transuranic elements entail some environmental impact. Probably the most severe of these are the noise level during launch and re-entry of the shuttle and contamination of the upper atmosphere from the chemical rockets. The environmental effects of disposal of the remaining waste will have to be added to that of the space-related operations. Another: launch site comparable to the existing Kennedy Space Center will be required.

The incremental environmental impact of actinide transmutation in LWRs would be minimal: Most effects can be attributed to the additional load on the nuclear fuel cycle. Since more fissile material is required to transmute the actinide elements, more uranium must be mined, more enrichment and processing facilities, and transportation are required, etc. As in the case of extraterrestrial disposal, additional environmental impacts would be involved in the disposal of the fission products.

a. The Tand use is generally controlled by the size of the "buffer" or zone of isolation around the actual disposal site. In this study, this zone was assumed to be 3.2 kilometers wide, which is in the range of 1.6 to 8 kilometers studied at ORNL for a geologic salt repository. 
Policy Conflicts

Both national and international policies which might apply to the disposal of nuclear waste were examined, although the results of these studies were not factored into the final program analysis.

The rules and regulations as established by the Atomic Energy Commission in 10 CFR 50 (Appendix F) have the most immediate national impact. These regulations clearly affect all liquid waste/melting disposal concepts, all extraterrestrial and ice sheet concepts and, most probably, the seabed concepts. "However, the AEC rules and regulations appear to be more easily modified than international treaties.

The Antarctic Treaty of 1959 is an international agreement specifically prohibiting any disposal of radinactive waste material in the Antarctic. This would clearly affect all ice sheet disposal concepts envisioning use of the Antarctic. This treaty is in effect until 1989, at which time any of the participants may suggest amendments.

If the Greenland ice sheet were considered as a waste repository, negotiations must be effected with Denmark.

The Nuclear Test Ban Treaty might affect the concepts using nuclear explosives. Any release of radioactive materials across international boundaries is prohibited.

The Nonproliferation Treaty could conceivably impinge on any of the concepts since it provides for the safeguarding of all source and special fissionable materials. The treaty specifies that International Atomic Energy Agency safeguard standards must be observed in all peaceful nuclear activities whether within a state or under its control anywhere.

The Treaty on Outer Space of 1967 and the Convention on International Liability for Damage Caused by Space 0bjects of 1972 (not yet ratified by the U.S.) would affect all extraterrestrial concepts. These treaties define the responsibilities of parties to the treaty in any space launch operations.

The seabed and ice sheet disposal concepts would most probably be impacted by the Convention on the High Seas and the Convention on the Continental Shelf of 1958. These treaties protect the high seas and the continental shelf respectively from pollution by radioactive waste. Additionally, the United States Marine Protection, Research, and Sanctuaries Act of 1972 prohibits transportation and disposa? at sea of radiological warfare agents and high-level radioactive waste.

\section{Public Response}

A method for measurement of the major elements of public perception of risk associated with nuclear waste was developed as part of this study. From the recommendations of a specifically assembled task force of advisors on risk and public acceptance, seven major elements of perceived risk were 
identified: distance, population density, emplacement operations, stability, detectability of leaks, retrievability, and protective reaction in event of a release of waste:

A research design questionnaire given before and after information regarding the waste disposal concepts was used in a preliminary pilot study based upon these seven elements of perceived risk. Five generic methods of nuclear waste disposal (geologic, ice sheet, seabed, high earth orbit, and surface retrievable storage) were used to illustrate a wide range of characteristics.

Although this experiment was administered to a small group and the resul.ts have limited significance, some of the results are interesting. Some judgments changed between the pre-test and post-test. After exposure to the information on the disposal concepts by videotape, the respondents perceived geologic disposal as being safer with respect to the elements of distance and stability but as more dangerous with respect to retrievability and protective reaction. Similarly, the ice sheet disposal method was perceived as being more dangerous for all elements of risk after information was presented. The standard deviation of the responses was almost universally less in the post-test than in the pre-test. All of these results suggest that the respondents have objective attitudes on risk which are subject to change with more detailed information.

Multiple regression analysis of the pilot survey results was inconclusive. However, it was concluded that this analytical technique can indirectly measure the respondents' attitudes. The technique could prove to be a useful approach towards measurement of public response to waste disposal concepts and perceived risk elements if the survey were administered to larger and more representative groups. With such information based on in depth analysis, public attitudes could be factored into concept design.

\section{SUMMARY OF HIGH-LEVEL RADIOACTIVE WASTE MANAGEMENT}

High-level radioactive waste in the U.S. will be converted to an encapsulated solid and shipped to a Federal repository for retrievable storage for extended periods. Meanwhile the AEC is actively pursuing the development of concepts for ultimate disposal of the waste which the Federal Government would manage. A number of promising concepts have been proposed, for which there is high confidence that one or more will be suitable for long-term, ultimate disposal.

Initial evaluations of technical (or theoretical) feasibility for the various waste disposal concepts show that in the broad category, (i.e., geologic, seabed, ice sheet, extraterrestrial, and transmutation) all meet the criteria for judging feasibility, though a few alternatives within these categories do not. 
Preliminary cost estimates show that, al though many millions of dollars may be required, the cost for even the most exotic concepts. is small relative to the total cost of electric power generation. For example, the cost estimates for terrestrial disposal concepts are less than $1 \%$ of the total generating costs. The cost for actinide transmutation is estimated at around 1\% of generation costs, while actinide element disposal in space is less than $5 \%$ of generating costs.

Thus neither technical feasibility nor cost seems to be a no-go factor in selecting a waste management system. The seabed, ice sheet, and space disposal concepts face international policy constraints. The information being developed currently in safety, environmental concern, and public response will be important factors in determining which concepts appear most promising for further development. 


\section{FIGURES}

I. PROJECTED U. S. NUCLEAR ELECTRICAL GENERATING CAPACITY

II. NUCLEAR FUEL LOGISTICS

III. CANISTERS OF SOLID HIGH-LEVEL WASTE.

IV. RETRIEVABLE SURFACE STORAGE FACILITY STORAGE UNIT

V. RELATIONSHIPS AMONG EVALUATION FACTORS

VI. $\because \quad$ INTERRELATIONSHIPS AMONG PATHWAY, PROBABILITY AND RISK

VII. CONCEPT FOR SOLID WASTE EMPLACEMENT. IN A MINED TUNNEL WITH NATURAL CONVECTION AIR COOLING

VIII: OPERATIONS IN SEABED DISPOSAL

IX. OPERATIONS IN ICE SHEET DISPOSAL

$x$ SHUTTLE LAUNCH DEPLOYMENT SEQUENCE FOR EXTRATERRESTRIAL DISPOSAL 


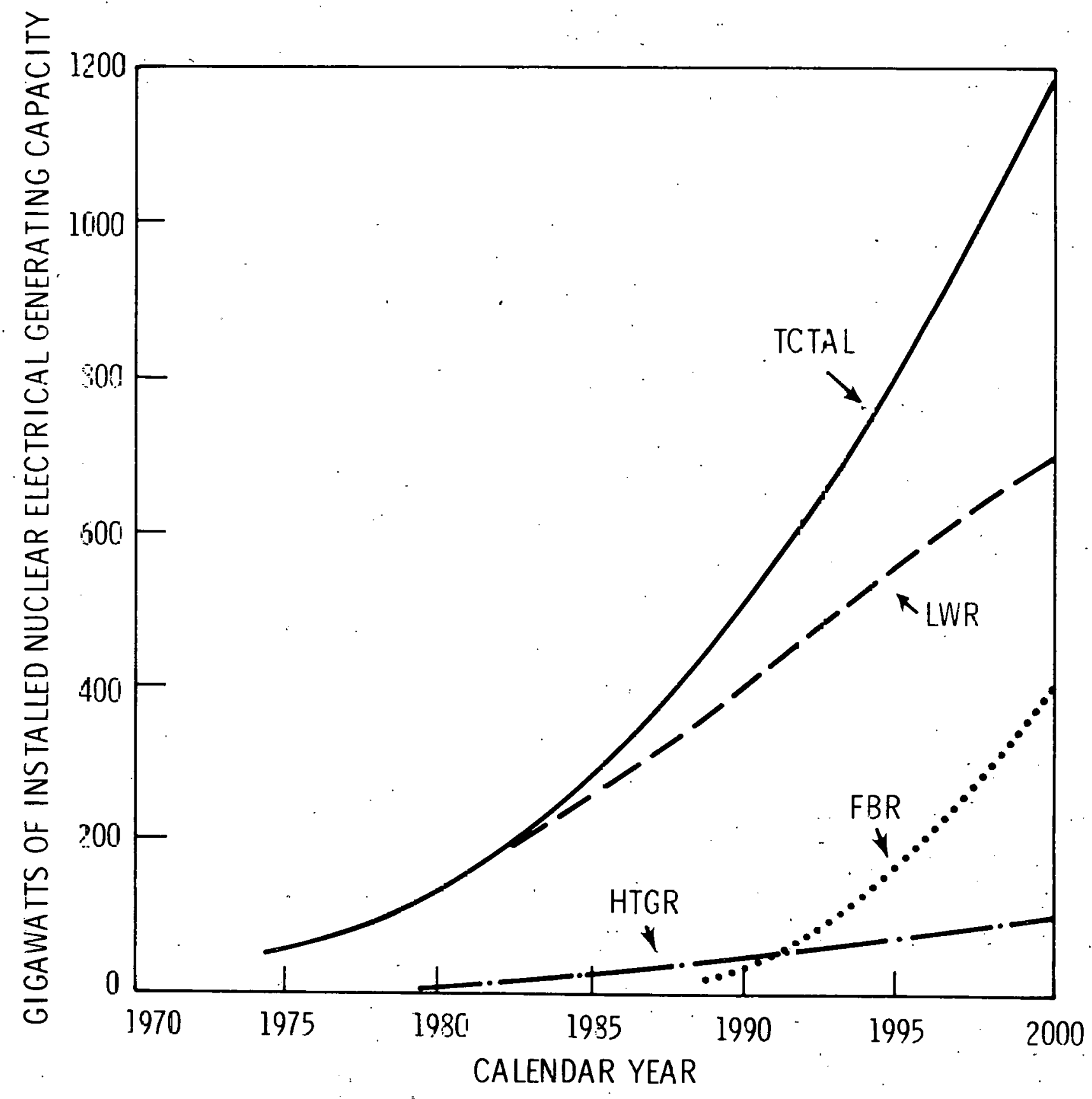

FIGUF: I. PROJECTED U. S. NUCLEAR ELECTRICAL GENERATING CAPACITY 


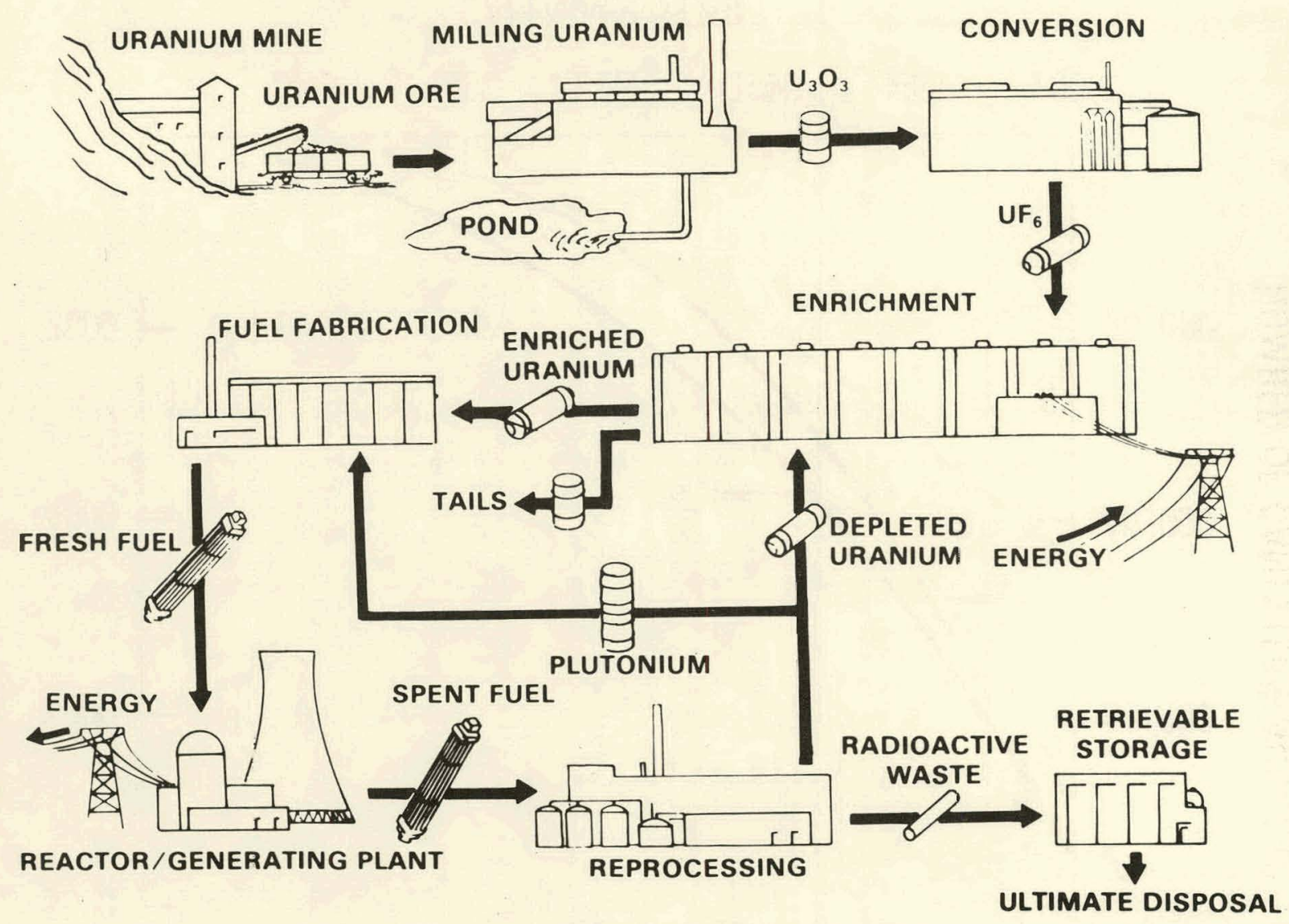

FIGURE II. NUCLEAR FUEL LOGISTICS 


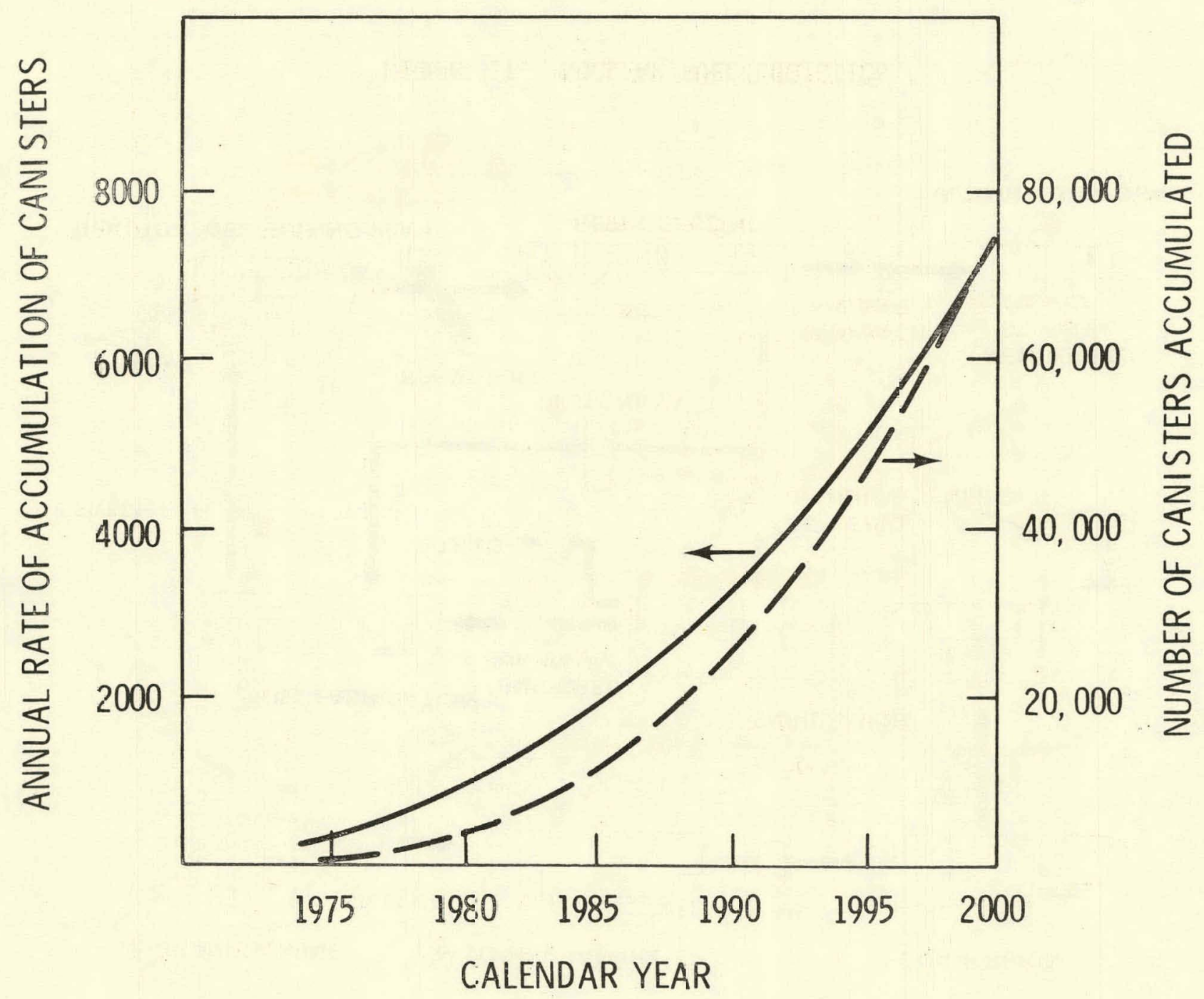

FIGURE III. CANISTER ACCUMULATION OF SOLID HIGH-LEVEL WASTE 


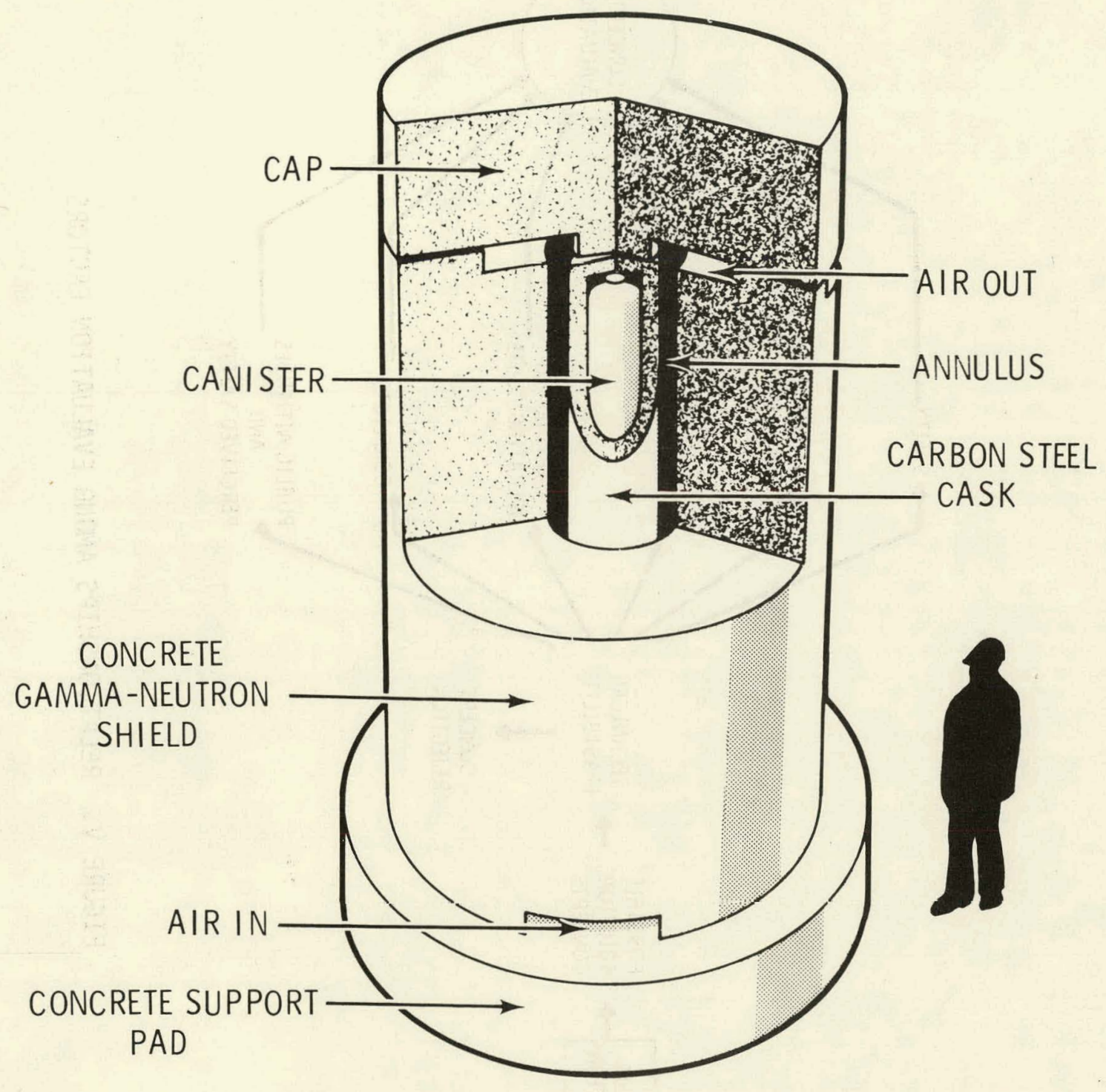

FIGURE IV. RETRIEVABLE SURFACE STORAGE FACILITY STORAGE UNIT 


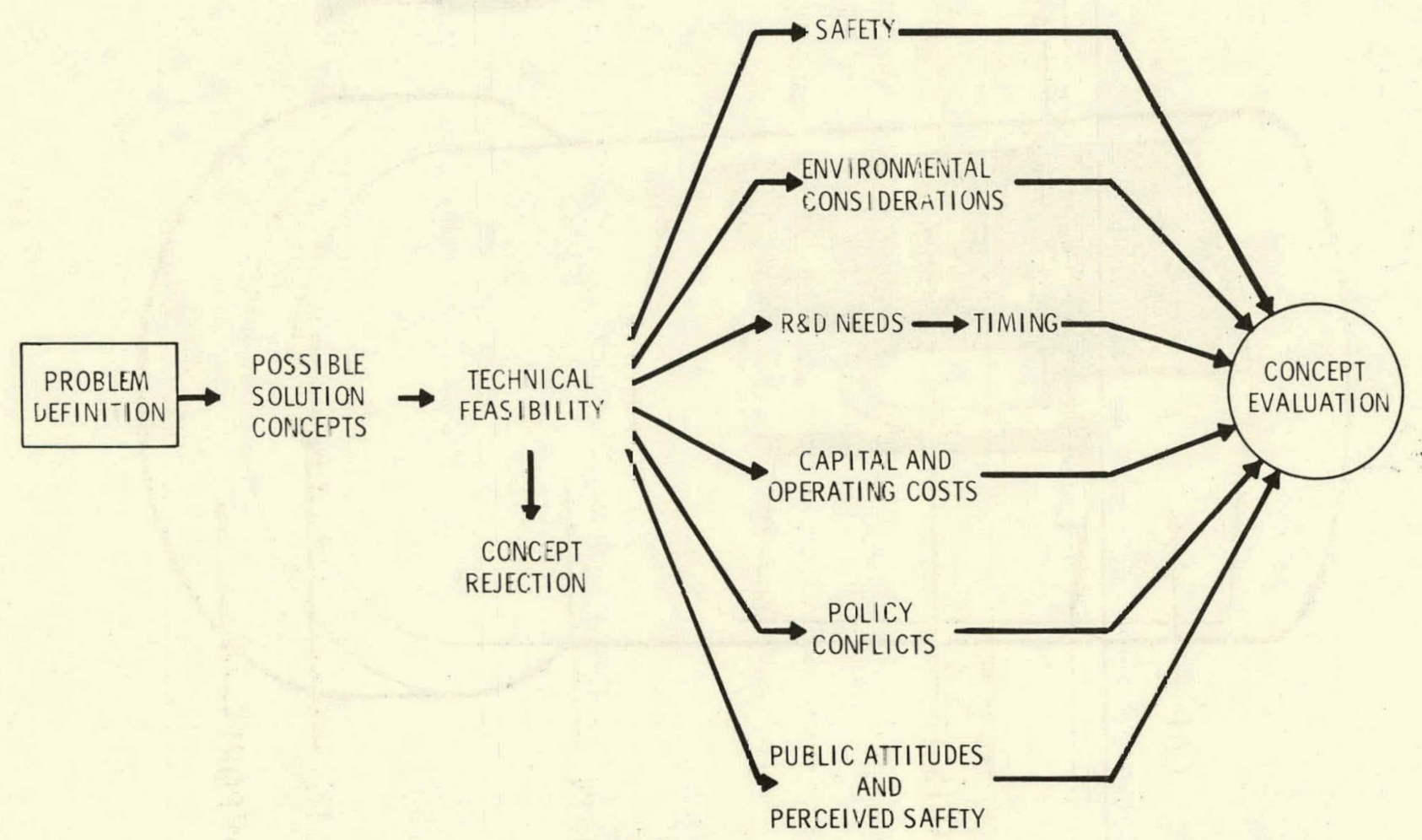

FIGURE V. RELATIONSHIPS AMONG EVALUATION FACTORS 


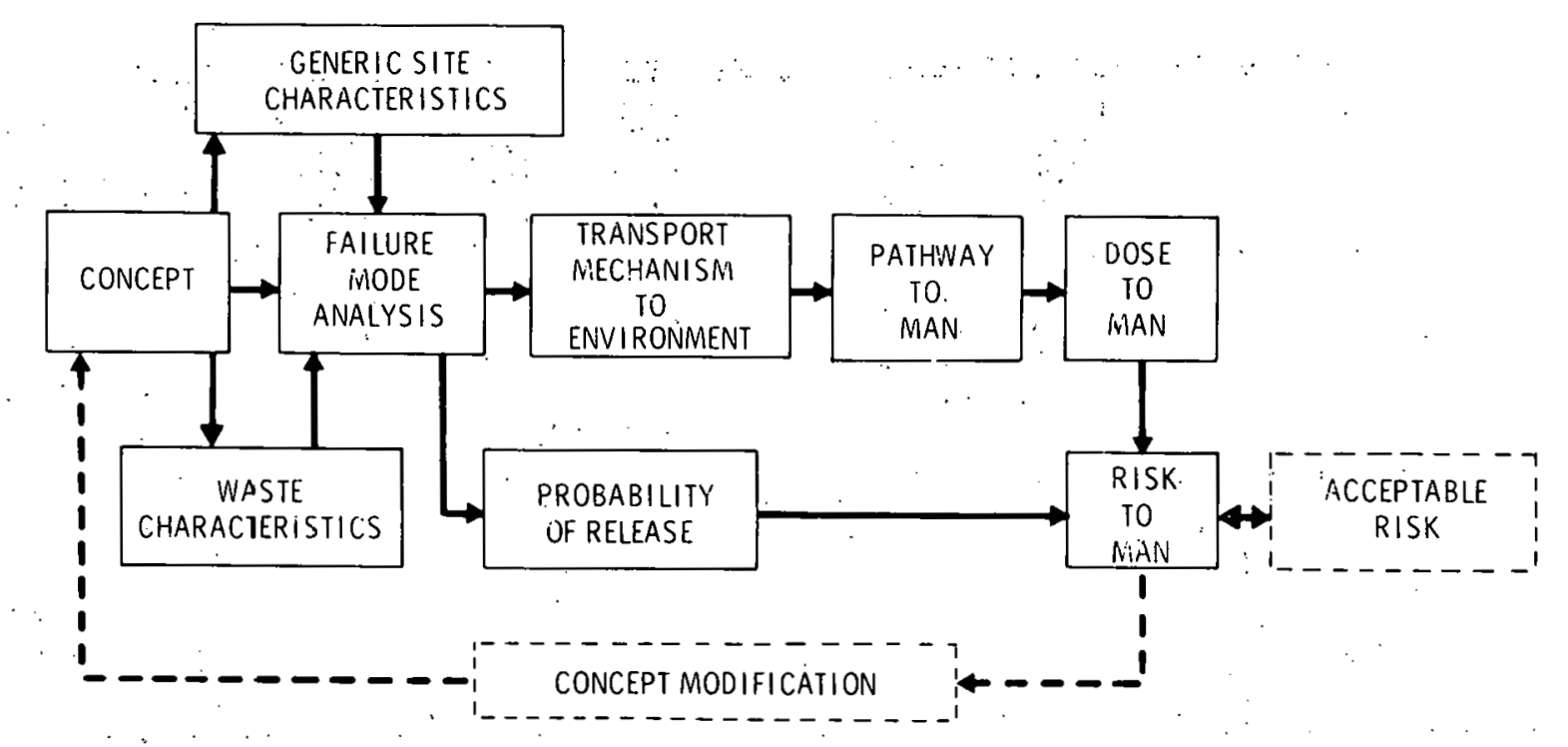

FIGURE VI. INTERRELATIONSHIPS AMONG PATHWAY, PROBABILITY AND RISK 


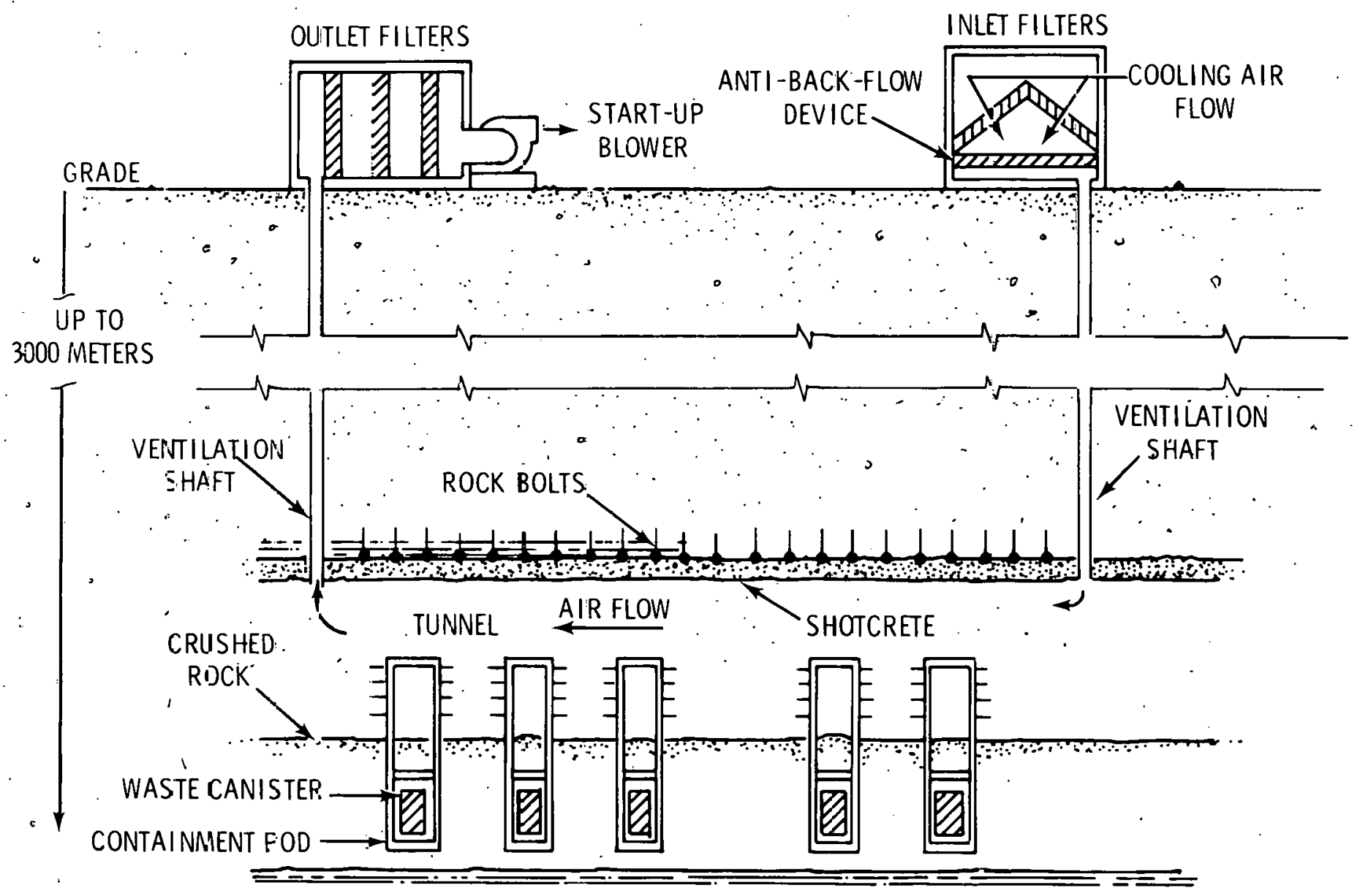

=IGUFE VII. CONCEPT FOR SOLID WASTE EMPLACEMENT IN A MINED TUNNEL WITH NATURAL CONVECTION AIR COOLING 


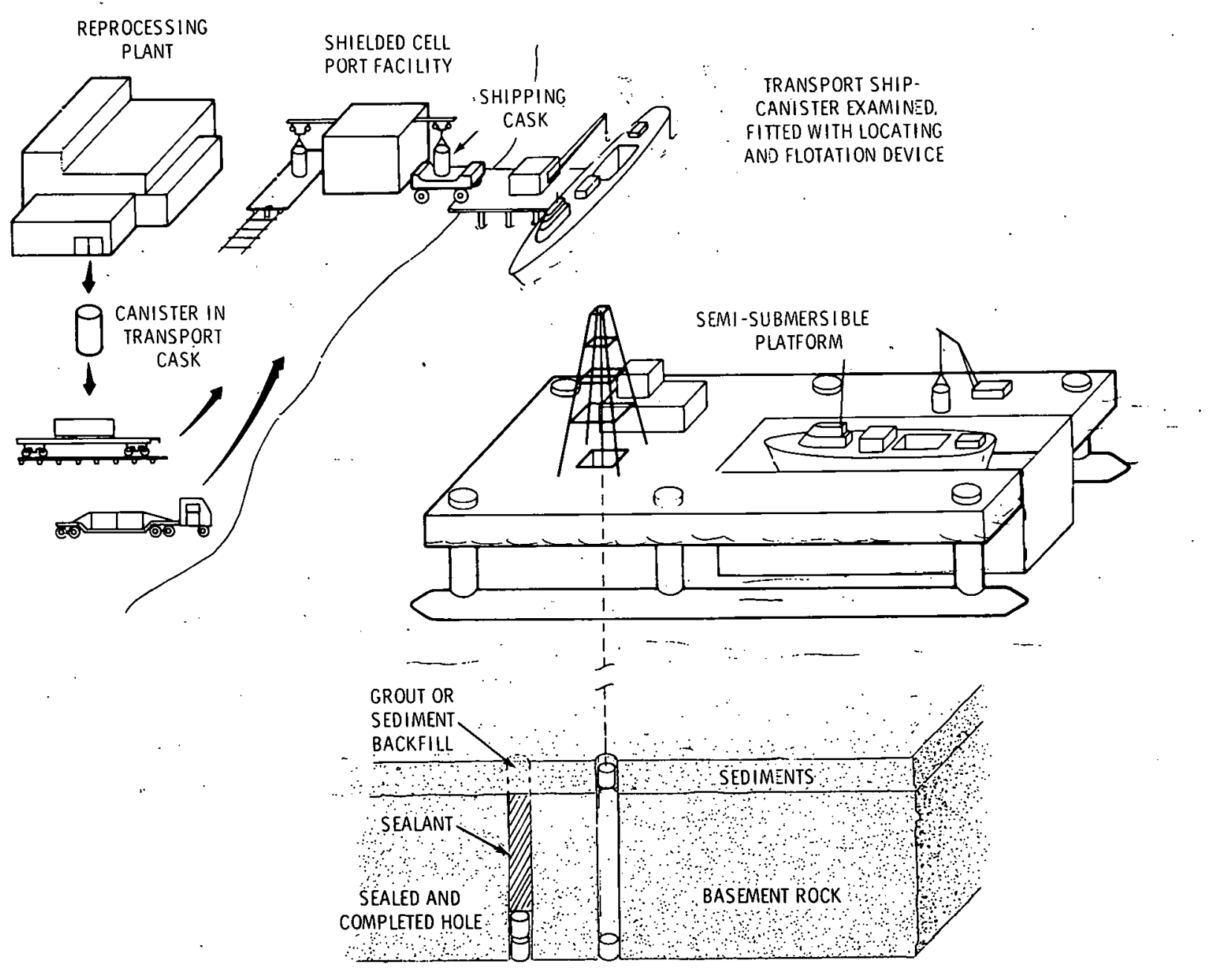

FIGURE VIII. OPERATIONS IN SEABED DISPOSAL 


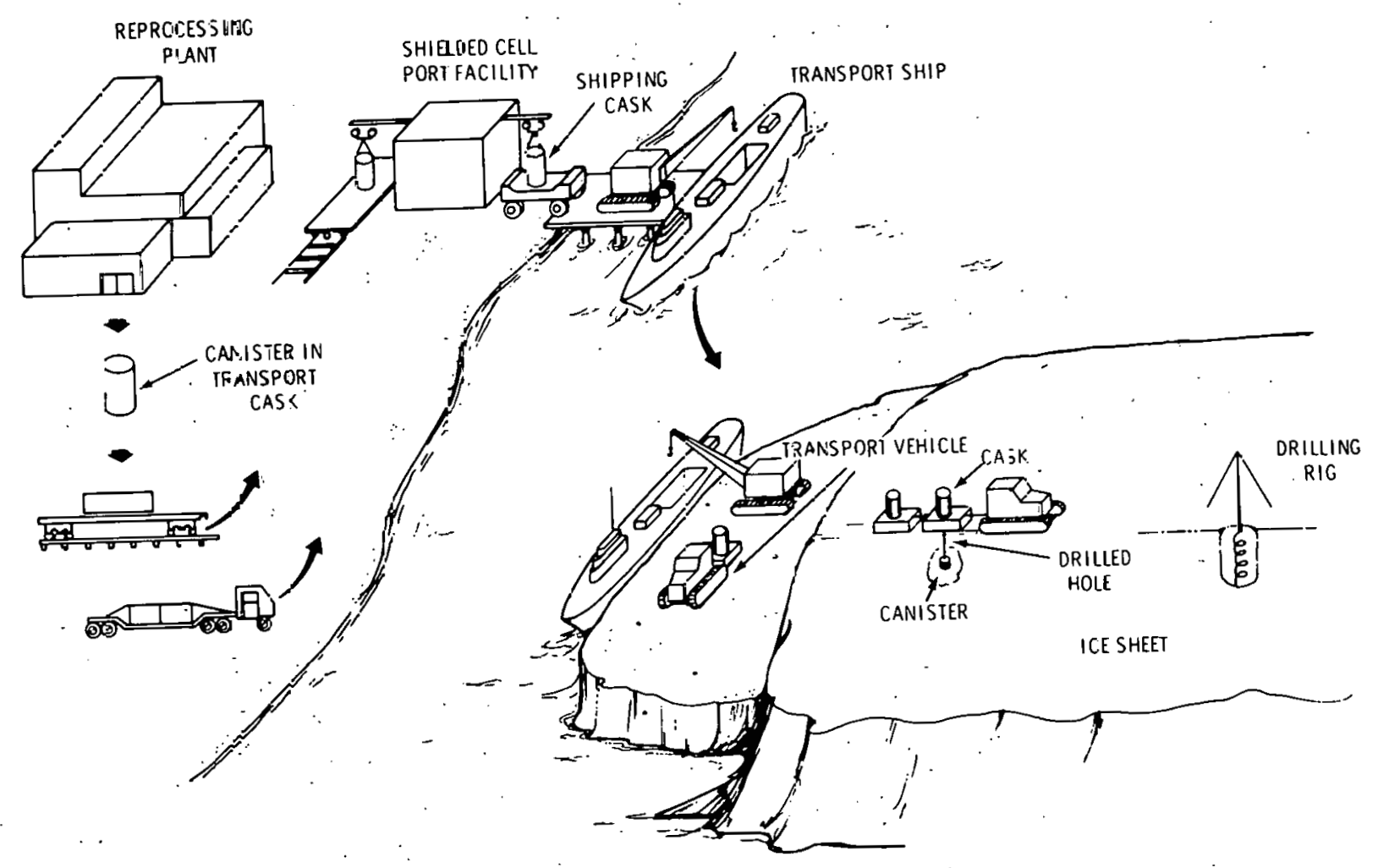

FIGURE IX. IJPERATIONS IN ICE SHEET DISPOSAL 


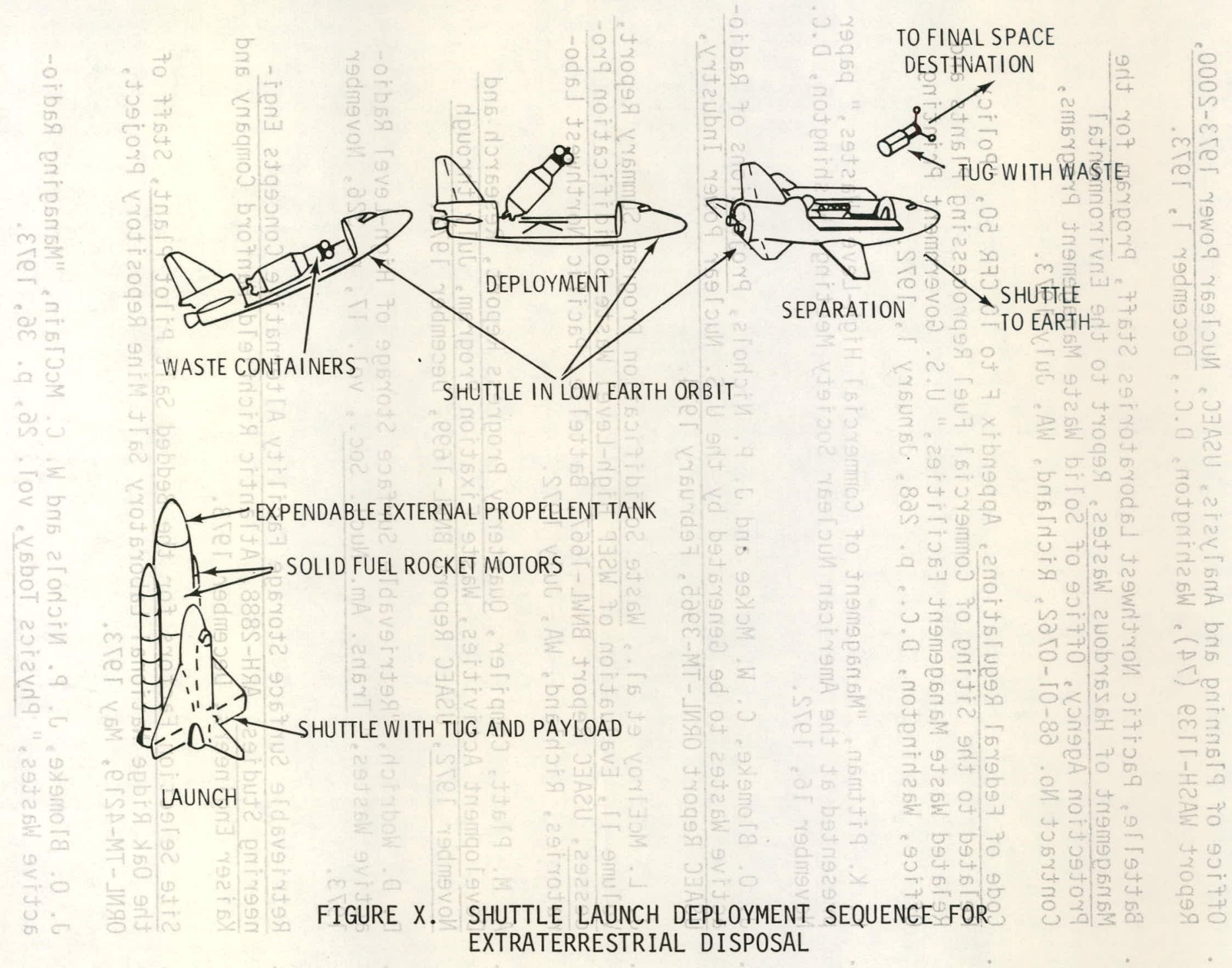




\section{REFERENCES}

1. Office of Planning and Analysis, USAEC, Nuclear Power 1973-2000, Report WASH-1139 (74), Wa shington, D.C., December 1, 1973.

2. Battelle, Pacific Northwest Laboratories Staff, Program for the Management of Hazardous Wastes, Report to the Environmental Protection Agency, Office of Sol id Waste Management Programs, Contract No. 68-01-0762, Richland, WA, July 1973.

3. Code of Federal Regulations, Appendix F to 10 CFR 50, "Policy Related to the Siting of Commercial Fuel Reprocessing Plants and Related Waste Management Facilities, "U.S. Government Printing. Office, Washington, D.C., p. 268, January 1, 1972.

4. F. K. Pillman, "Managenent of Comnerclal High-Level Wastes," paper presented at the American Nuclear Society Meeting, Washington, D.C., November 16, 1972.

5. J. 0. Blomeke, C. W. McKee and J. P. Nichols, Projections of Radioactive Wastes to be Generated by the U.S. Nuclear Power Industry, USAEC Report ORNL-TM-3965, February 1974.

6. J. L. McElroy et al., Waste Solidification Program Summary Report, Volume 11, Evaluation of WSEP High-Level Waste Solidification Processes, USAEC Report BNWL-7667, Batte17e, Pacific Northwest Laboratories, Richland, WA, July 1972.

7. A. M. Platt, Compiler, Quarterly Progress Report, Research and Development Activities, Waste Fixation Progiam, July through November 1972, USAEC Report BNWL-1699, December 1972.

8. D. D. Wodrich, "Retrievable Surface Storage of High-Level Radioactive Wastes," Trans. Am. Nucl. Soc., vo1. 17, p. 326, November 1973.

9. Retrievable Surface Storage Facility Alternative Concepts Engineering Studies, ARH-2888, Atlantic Richfield Hanford Company and Kaiser Engineers, December 1973.

10. Site Selection Factors for the Bedded Salt Pilot Plant, Staff of the Oak Ridge National Laboratory Salt Mine Repository Project, ORNL-TM-4219, May 1973.

11. J. 0. Blomeke, J. P. Nichols and W. C. McClain; "Mañaging Radioactive Wastes," Physics Today, vo1. 26, p. 36, 1973 . 
12. K. J. Schneider and J. H. Jarrett, "Alternative Means of Ultimate High-Level Waste Management," Trans. Am. Nucl. Soc. vol. 17, p. 325 November 1973.

13. Division of Waste Management and Transportation, USAEC, High-Level Radioactive Waste Management Alternatives, WASH-1297, USAEC Division of Waste Management and Transportation, Washington, D.C., May 1974.

14. K. J. Schneider and A. M. Platt, Editors, Advanced Waste Management Studies, High-Level Radioactive Waste Disposal Alternatives, USAEC Report BNWL-1900, Battelle, Pac ific Northwest Laboratories, Richland WA, Sections 1 through 9 in 4 Volumes, May 1974.

15. E. B. Ekren et al., Geologic and Hydrologic Considerations for Various Concepts of High-Level Radioactive Waste Disposal in Conterminous United States, USGS Report 2198-1, Department of the Interior, Geological Survey, Federal Center, Denver, C0, 1974.

16. E. J. Zeller, D. F. Sanders and E. E. Angino, "Putting Radioactive Wastes on Ice," Bulletin of the Atomic Scientists, January 1973.

17. R. E. Hyland et al., Feasibility of Space Disposal of Radioactive Nuclear Waste, I-Executive Summary, NASA Technical Memorandum TMX-2911, NASA-Lewis Research Center, Cleveland, OH, December 1973.

18. H. C. Claiborne, Neutron-Induced Transmutation of High-Level Radioactive Waste, USAEC Report, ORNL-TM-3964, Oak Ridge National Laboratory, December 1972.

19. A. S. Kubo, Technology Assessment of High-Level Nuclear Waste Management, SCD Thesis, Department of Nuclear Eng ineering, Massachusetts Institute of Technology, April 1973.

20. A. S. Kubo and D. J. Rose, "Disposal of Nuclear Wastes," Science, vol. 182, p. 1205, December 21, 1973.

21. W. C. Wolkenhauer et a1., Transmutation of High-Level Radioactive Waste with a Controlled Thermonuclear Reactor, USAEC Report BNWL-1772, Battel1e, Pacific Northwest Laboratories, September 1973. 